\title{
Reciprocal and continuous rotation is two sides of the same coin
}

\begin{abstract}
The birth of modern Endodontic occurred with the appearance of NiTi rotary instruments on market around 1993. The reciprocal and continuous rotational tools are successive evolutions of the rotary motion techniques, which are closely associated with rapid cleaning and shaping of the root canal system. ${ }^{1}$ A multitude of studies has been performed in the last years, substantiating their high efficiencies, studying their specific characteristics, proposing unifying theories, and testing possible countermeasures. ${ }^{2,3}$ To date, however, the role of an instrument's motion in long-term researches has not been explicitly tested. Here the literature review was specifically interested in whether an instrument's motion patterns can affect its characteristics. To that end, we used a simple classification where both movements were categorized on the basis of dynamic properties such as cyclic fatigue, And biological properties (apical extrusion of bacteria). ${ }^{4}$
\end{abstract}

Keywords: reciprocal, continuous, cutting efficiency, cyclic fatigue, cracks, bacterial, extrusion
Volume 9 Issue $3-2018$

\author{
Sarah Salloum, Chadi Torbey, Sanaa Bassam, \\ Claudia DIB \\ Department of Dentistry, Lebanese University, Lebnon
}

Correspondence: Sarah Salloum, Department of Dentistry, Lebanese University, Lebanon, Tel 0096170600753 ,

Email sas.salloum@gmail.com

Received: May 24, 2018 | Published: June 18, 2018

\section{Introduction}

One of the most fundamental tasks for the endodontist is to recognize the instruments that are mostly used in Root canal treatment. In order to do this task it is assumed that he should be aware of all their properties for optimal recognition performance. ${ }^{1}$ For example, a shape or part structure, color, or texture may reveal information unique to this instrument that can be used for recognition. ${ }^{5}$ However, those files are not stationary and the manner in which an instrument moves can often act as a unique signature for the identity of it. ${ }^{1,5}$ Therefore, the aim of the present study wasn't to decide whether to choose between reciprocal or continuous motions. The two techniques may give the same success rate but they are significantly different in their theory, application procedures, characteristics and form of the results. ${ }^{6}$

\section{Cyclic fatigue}

Fatigue is an important parameter for determining the behavior of mechanical files functioning under variable loads. The fatigue resistance of a structural component is affected by mechanical, metallurgical, and environmental variable factors. ${ }^{7,8}$ Fatigue is the primary reason for $80-90 \%$ of instrument fracture. Hence, In the case of rotary instruments, the files often break due to over usage or to the complexity of the root canal system. ${ }^{1}$ Many papers reported that the reciprocal motion was associated with significantly higher cyclic fatigue resistance than with continuous one., ${ }^{91,11,12}$ The results obtained are shown in the graph below (Figure 1). According to this graph, the reciprocal instruments may be used more often than the continuous ones before they break. As a matter of fact, PerezHigueras et al reported that many continuous rotation instruments had better cyclic fatigue resistance when moved with reciprocating motion $\left(144^{\circ} \mathrm{CW}\right.$ and $\left.72^{\circ} \mathrm{CCW}\right) .^{13,14}$ Perhaps the most compelling evidence is the evaluation done by De-Deus et al., ${ }^{15,16}$ they found that the reciprocating motion significantly extended the cyclic fatigue life of the originally continuous rotation ProTaper F2 instrument, compared to conventional rotation. Several other publications outlined the same result using other types of instruments. ${ }^{17-22}$ There is not only a significant difference between reciprocation and continuous rotation but also a significant difference between different reciprocating motions with different angles of rotation. ${ }^{23}$ Remodeling the amplitude of reciprocation has a significant influence on the cyclic fatigue life of NiTi files. ${ }^{24}$ By the same token, Gambarini et al stated that the differences in the cyclic fatigue resistance of different reciprocating angles may be inversely proportional to the angle of rotation. ${ }^{23}$ However, regardless of the instruments used in the mentioned studies, the most important variable affecting the cyclic fatigue of the files remains the complexity of the system. The more complex is the root canal, the less is the resistance..$^{21,25}$

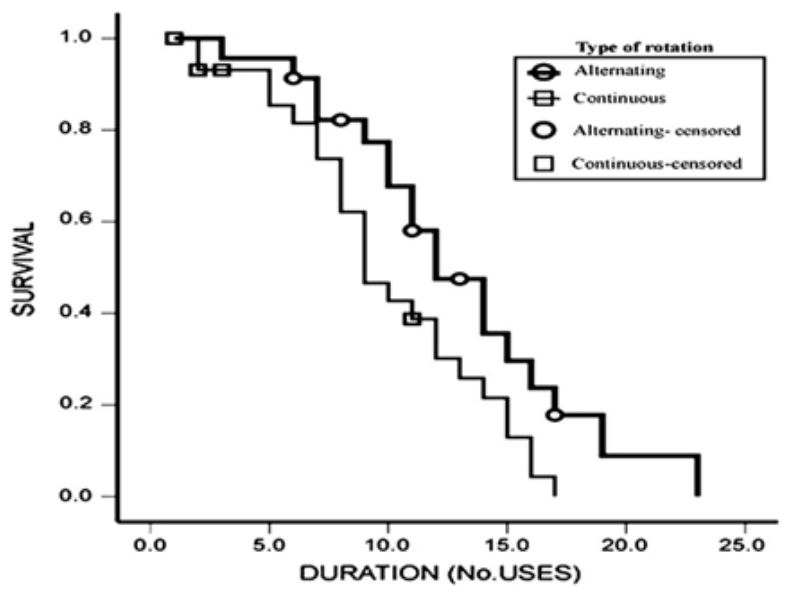

Figure I Survival curves (duration) of the instruments with the two types of movement.

\section{Cutting efficiency}

The object of cutting efficiency is to remove the maximum amount of tooth structure with the minimum amount of effort and time, and several factors are involved. Cutting efficiency may be improved with a technic that allows bulk removal of tooth structure to depths controlled by the instrument. ${ }^{1,26}$ Even though the higher the cutting efficiency is, the less time and action it takes, this feature may lead 
to higher accumulation of debris in the canal. Therefore, the cleaning of the canal will be harder and the screw-in effect may be frequent in such cases. ${ }^{1}$ Many Reports have shown that Reciprocal tools have a higher cutting efficiency than the continuous tools. However, after excluding the effect of the design and alloy variables, Stern et al., ${ }^{27}$ found that using a single ProTaper F2 Universal instruments with the reciprocating motion of ATR Technika motors removed a similar dentine volume to that produced when using a full sequence of the same instrument with rotational motions. ${ }^{27}$ Other studies also found no differences in cutting efficiency when comparing same instruments in different kinematics indicating that the type of movement has no effect on the cutting capacity of instruments. ${ }^{28}$

\section{Dentinal damage and apical transportation}

Vertical root fractures (VRFs) are mostly resulted from a poor prognosis for the affected tooth and should therefore be avoided. ${ }^{1}$ Local stress concentrations have been presented as the starting point of VRFs. Dentin defects, created by rotary instruments, may act as stress concentration areas, spread from recurred stresses generated as a result of further endodontic and restorative procedures, and ultimately develop into a VRF. ${ }^{29-32}$ To prevent VRFs, safer instruments and techniques should be sought and preferred. ${ }^{33}$ Accordingly, many authors such as Rui Liu et al., ${ }^{34}$ had listed in their researches that it is much safer to use Reciproc files due to the fact of producing less dentinal cracks. ${ }^{35,36}$ The results supporting this conclusion are shown in the histogram below (Figure 2) ${ }^{34}$ However, recently, Hwang et al. reported that there was no causal relationship between canal preparation with rotary/reciprocating systems and micro-cracks formation. ${ }^{37}$ On the other hand, NiTi systems with different motions have been produced to maintain the original canal shape and thus keep it better centered. ${ }^{38-41}$ Reciprocating single instruments may show better centering in the root canal due to the fact that a single file is used to shape the canal rather than a gradual sequence used in continuous rotating instruments. ${ }^{42,9}$ But other studies showed that rotary instruments resulted in less transportation than reciprocating instruments. In the study of Zhao et al. ${ }^{43}$ ProTaper Universal and WaveOne made similar canal curvature transportation, whereas ProTaper Next had significantly less transportation. This difference can be explained by the taper of ProTaper Next being less than ProTaper Universal and WaveOne. ${ }^{43}$

\section{Bacterial apical extrusion}

Cleaning and shaping of root canal system is a main act during endodontic therapy. One of the weightiest complications might be the apical extrusion of bacteria during the instrumentation procedures. ${ }^{44,45}$ Less bacterial extrusion means lower risk of reinfection. On the positive side, Researchers have become progressively concerned about reciprocating files. Consequently, favorable results might be predictable. On the negative side, a wide range of experimental papers on the issue have come to inconsistent conclusions. ${ }^{46,47}$ One article compared debris extrusion associated with ProTaper and Mtwo with that of Reciproc and WaveOne, it was found that more debris extrusion was associated with the latter 2 systems. ${ }^{48}$ On the other hand, others reported that reciprocating instruments produced less debris extrusion compared with rotary instrumentation. ${ }^{49-53}$ Also a number of studies showed no significant difference between the two systems. ${ }^{54}$ The probable reasons of the conflicting results could be the variability of files designs, the number of files used and the canal anatomy differences between the studies.

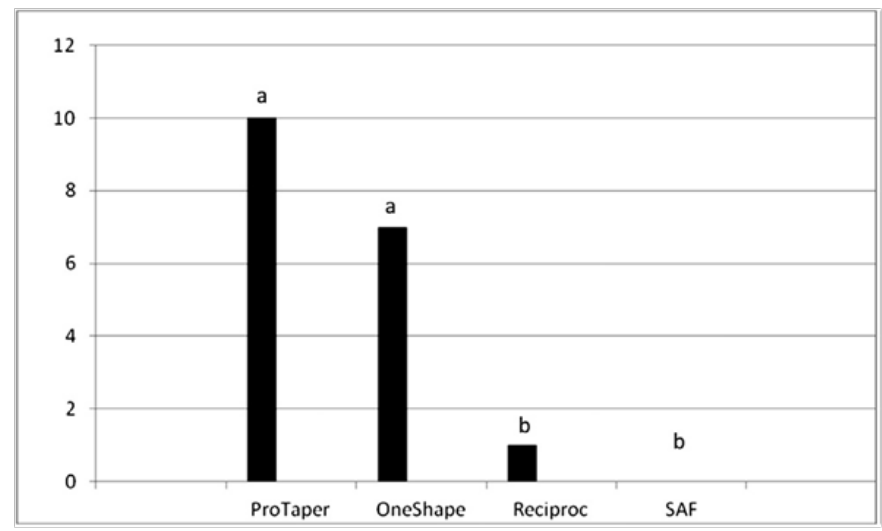

Figure $\mathbf{2}$ The total number of cracked teeth with different instrumentation techniques. Different letters denote statistical significance.

\section{Conclusion}

In conclusion, various methods have been used to measure the results in validation studies. This study concludes that the Reciprocal motion is the most adequate motion that has been used for an ultimate treatment result..$^{55}$ Reciprocal files have a better fatigue resistance, a better cutting efficiency and a minimum of dentinal damage. ${ }^{55,56}$ However, reciprocal and continuous instruments have the same success rate. ${ }^{6}$ Besides, some cases might only be worked with continuous motion technique. Hence, it is important for the clinician and medical researcher to be aware of this issue because erroneous and misleading conclusions from random papers may lead to the application of inaccurate instruments in clinical practice..$^{57-61}$

\section{Acknowledgements}

None.

\section{Conflict of interest}

The author declares that there is no conflict of interest.

\section{References}

1. Berman L, Cohen S, Hargreaves K. Cohen's Pathways of the pulp. $11^{\text {th }}$ ed. 2016.

2. Lopes H, Gambarra-Soares T, Elias C, et al. Comparison of the Mechanical Properties of Rotary Instruments Made of Conventional Nickel-Titanium Wire, M-Wire, or Nickel-Titanium Alloy in R-Phase. $J$ Endod. 2013;39(4):516-520.

3. Yared G, Bou Dagher F, Machtou P. Influence of rotational speed, torque and operator's proficiency on ProFile failures. Int Endod J. 2001;34(1):47-53.

4. Bhatt A, Goel A, Rastogi R, et al. An Overview of Modern Endodontic Niti Systems. International Journal of Scientific Research . 2015;4(4):595-597.

5. Jordan L, Sultan A, Vermaut P. Microstructural and mechanical characterizations of new Ni-Ti endodontic instruments. MATEC Web of Conferences. 2015;33:03005.

6. Plotino G, Ahmed H, Grande N, et al. Current Assessment of Reciprocation in Endodontic Preparation: A Comprehensive Review-Part II: Properties and Effectiveness. Journal of Endodontics. 2015;41(12):1939-1950. 
7. Capar I, Ertas H, Arslan H. Comparison of Cyclic Fatigue Resistance of Nickel-Titanium Coronal Flaring Instruments. $J$ Endod. 2014;40(8):1182-1185.

8. Gambarini G, Plotino G, Grande N, et al. Mechanical properties of nickel-titanium rotary instruments produced with a new manufacturing technique. Int Endod J. 2011;44(4):337-341.

9. Ahn S, Kim H, Kim E. Kinematic Effects of Nickel-Titanium Instruments with Reciprocating or Continuous Rotation Motion: A Systematic Review of In Vitro Studies. J Endod. 2016;42(7):1009-1017.

10. Ferreira F, Adeodato C, Barbosa I, et al. Movement kinematics and cyclic fatigue of NiTi rotary instruments: a systematic review. Int Endod J. 2016;50(2):143-152.

11. Kiefner P, Ban M, De-Deus G. Is the reciprocating movement able to improve the cyclic fatigue resistance of instruments? Int Endod J. 2013;47(5):430-436.

12. Kim H, Kwak S, Cheung G, et al. Cyclic Fatigue and Torsional Resistance of Two New Nickel-Titanium Instruments Used in Reciprocation Motion: Reciproc Versus WaveOne. J Endod. 2012;38(4):541-544.

13. Pérez-Higueras J, Arias A, de la Macorra J, et al. Differences in Cyclic Fatigue Resistance between ProTaper Next and ProTaper Universal Instruments at Different Levels. J Endod. 2014;40(9):1477-1481.

14. Pérez-Higueras J, Arias A, de la Macorra J. Cyclic Fatigue Resistance of K3, K3XF, and Twisted File Nickel-Titanium Files under Continuous Rotation or Reciprocating Motion. J Endod. 2013;39(12):1585-1588.

15. De-Deus G, Moreira E, Lopes H, et al. Extended cyclic fatigue life of F2 ProTaper instruments used in reciprocating movement. Int Endod J. 2010;43(12):1063-1068.

16. De-Deus G, Silva E, Vieira V, et al. Blue Thermomechanical Treatment Optimizes Fatigue Resistance and Flexibility of the Reciproc Files. $J$ Endod. 2017;43(3):462-466.

17. Gambarini G, Gergi R, Naaman A, et al. Cyclic fatigue analysis of twisted file rotary NiTi instruments used in reciprocating motion. Int Endod J. 2012;45(9):802-806.

18. Nguyen H, Fong H, Paranjpe A, et al. Evaluation of the Resistance to Cyclic Fatigue among ProTaper Next, ProTaper Universal, and Vortex Blue Rotary Instruments. J Endod. 2014;40(8):1190-1193.

19. Pedullà E, Corsentino G, Ambu E, et al. Influence of continuous rotation or reciprocation of Optimum Torque Reverse motion on cyclic fatigue resistance of nickel-titanium rotary instruments. Int Endod J. 2018;51(5):522-528.

20. Pedullà E, Grande N, Plotino G, et al. Influence of Continuous or Reciprocating Motion on Cyclic Fatigue Resistance of 4 Different Nickel-Titanium Rotary Instruments. Journal of Endodontics. 2013;39(2):258-261.

21. Rubini A. Influence of file motion on cyclic fatigue of new nickel titanium instruments. Ann Stomatol. 2013;4(1):149-51.

22. Wan J, Rasimick B, Musikant B, et al. A comparison of cyclic fatigue resistance in reciprocating and rotary nickel-titanium instruments. Aust Endod J. 2010;37(3):122-127.

23. Gambarini G, Rubini A, Al Sudani D, et al. Influence of Different Angles of Reciprocation on the Cyclic Fatigue of Nickel-Titanium Endodontic Instruments. JOE. 2012;38(10):1408-1411.

24. Saber S, El Sadat S. Effect of Altering the Reciprocation Range on the Fatigue Life and the Shaping Ability of WaveOne Nickel-Titanium Instruments. J Endod. 2013;39(5):685-688.
25. Zelada G, Varela P, Martin B, et al. The Effect of Rotational Speed and the Curvature of Root Canals on the Breakage of Rotary Endodontic Instruments. J Endod. 2002;28(7):540-542.

26. Young G, Parashos P, Messer H. The principles of techniques for cleaning root canals. Aust Dent J. 2007;52(1 Supp1):S52-S63.

27. Stern S, Patel S, Foschi F, et al. Changes in centring and shaping ability using three nickel-titanium instrumentation techniques analysed by micro-computed tomography ( $\mu \mathrm{CT}$ ). Int Endod J. 2012;45(6):514-523.

28. Suffridge C, Hartwell G, Walker T. Cleaning Efficiency of NickelTitanium GT and .04 Rotary Files when used in a Torque-Controlled Rotary Handpiece. J Endod. 2003;29(5):346-348.

29. Capar I, Arslan H, Akcay M, et al. Effects of ProTaper Universal, ProTaper Next, and HyFlex Instruments on Crack Formation in Dentin. J Endod. 2014;40(9):1482-1484.

30. Karataş E, Gündüz H, Kirici D, et al. Dentinal Crack Formation during Root Canal Preparations by the Twisted File Adaptive, ProTaper Next, ProTaper Universal, and WaveOne Instruments. $J$ Endod. 2015;41(2):261-264.

31. Kim H, Lee M, Yum J, et al. Potential Relationship between Design of Nickel-Titanium Rotary Instruments and Vertical Root Fracture. J Endod. 2010;36(7):1195-1199.

32. Yoldas O, Yilmaz S, Atakan G, et al. Dentinal Microcrack Formation during Root Canal Preparations by Different NiTi Rotary Instruments and the Self-Adjusting File. J Endod. 2012;38(2):232-235.

33. Jamleh A, Adorno C, Ebihara A, et al. Effect of nickel titanium file design on the root surface strain and apical microcracks. Australian Endodontic Journal. 2015;42(1):25-31.

34. Liu R, Hou B, Wesselink P, et al. The Incidence of Root Microcracks Caused by 3 Different Single-file Systems versus the ProTaper System. $J$ Endod. 2013;39(8):1054-1056.

35. Bayram H, Bayram E, Ocak M, et al. Effect of ProTaper Gold, Self-Adjusting File, and XP-endo Shaper Instruments on Dentinal Microcrack Formation: A Micro-computed Tomographic Study. J Endod. 2017;43(7):1166-1169.

36. Kansal R, Rajput A, Talwar S, et al. Assessment of Dentinal Damage during Canal Preparation Using Reciprocating and Rotary Files. J Endod. 2014;40(9):1443-1446.

37. Hwang YH, Bae KS, Baek SH, et al. Shaping ability of the conventional nickeltitanium and reciprocating nickel-titanium file systems: a comparative study using micro-computed tomography. $J$ Endod. 2014;40(8):1186-9.

38. Capar I, Arslan H. A review of instrumentation kinematics of enginedriven nickel-titanium instruments. Int Endod J. 2015;49(2):119-135.

39. Glassman G, Gambarini G, Rosler S. Twisted Files and Adaptive Motion Technology: A Winning Combination for Safe and Predictable Root Canal Shaping. Oral Health. 2016.

40. Marzouk A, Ghoneim A. Computed Tomographic Evaluation of Canal Shape Instrumented by Different Kinematics Rotary Nickel-Titanium Systems. J Endod. 2013;39(7):906-909.

41. Wu M, Fan B, Wesselink P. Leakage Along Apical Root Fillings in Curved Root Canals. Part I: Effects of Apical Transportation on Seal of Root Fillings. J Endod. 2000;26(4):210-216.

42. Abu Haimed A, Abuhaimed T, Dummer P, et al. The root canal shaping ability of WaveOne and Reciproc versus ProTaper Universal and Mtwo rotary NiTi systems. Saudi Endodontic Journal. 2017;7(1):8-15. 
43. Zhao D, Shen Y, Peng B, et al. Root Canal Preparation of Mandibular Molars with 3 Nickel-Titanium Rotary Instruments: A Micro-Computed Tomographic Study. J Endod. 2014;40(11):1860-1864.

44. Capar I, Arslan H, Akcay M, et al. An In Vitro Comparison of Apically Extruded Debris and Instrumentation Times with ProTaper Universal, ProTaper Next, Twisted File Adaptive, and HyFlex Instruments. J Endod. 2014;40(10):1638-41.

45. Koçak $M$, Çiçek E, Koçak S, et al. Apical extrusion of debris using ProTaper Universal and ProTaper Next rotary systems. Int Endod J. 2014;48(3):283-286.

46. Bürklein S, Benten S, Schäfer E. Quantitative evaluation of apically extruded debris with different single-file systems: Reciproc, F360 and OneShape versus Mtwo. Int Endod J. 2013;47(5):405-409.

47. Bürklein S, Schäfer E. Apically Extruded Debris with Reciprocating Single-File and Full-sequence Rotary Instrumentation Systems. J Endod. 2012;38(6):850-852.

48. Karatas E, Arslan H, Topcu M, et al. Quantitative evaluation of apically extruded debris during root canal instrumentation with ProTaper Universal, ProTaper Next, WaveOne, and self-adjusting file systems. Eur J Dent. 2014;8(4):504-8.

49. De-Deus G, Brandão M, Barino B, et al. Assessment of apically extruded debris produced by the single-file ProTaper F2 technique under reciprocating movement. Oral Surg Oral Med Oral Pathol Oral Radiol Endod. 2010;110(3):390-394.

50. De-Deus G, Neves A, Silva E, et al. Apically extruded dentin debris by reciprocating single-file and multi-file rotary system. Clin Oral Investig. 2015;19(2):357-361.

51. De-Deus G, Nogueira Leal Silva E, et al. Assessment of Apically Extruded Debris Produced by the Self-Adjusting File System. J Endod. 2014;40(4):526-529.
52. Koçak S, Koçak M, Sağlam B, et al. Apical Extrusion of Debris Using SelfAdjusting File, Reciprocating Single-file, and 2 Rotary Instrumentation Systems. J Endod. 2013;39(10):1278-1280.

53. Tinoco J, De-Deus G, Tinoco E, et al. Apical extrusion of bacteria when using reciprocating single-file and rotary multifile instrumentation systems. Int Endod J. 2013;47(6):560-566.

54. Vivekanandhan P, Mitthra S, Karthick A. Comparison of apical debris extrusion of two rotary systems and one reciprocating system. J Conserv Dent. 2016;19(3):245-9.

55. Grande N, Ahmed H, Cohen S, et al. Current Assessment of Reciprocation in Endodontic Preparation: A Comprehensive Review-Part I: Historic Perspectives and Current Applications. J Endod. 2015;41(11):1778-1783.

56. Junaid A, Ensinas P, Nudera W, et al. Assessment of the Separation Incidence of Reciprocating WaveOne Files: A Prospective Clinical Study. J Endod. 2014;40(7):922-924.

57. Shen Y, Zhou H, Zheng Y, et al. Current Challenges and Concepts of the Thermomechanical Treatment of Nickel-Titanium Instruments. J Endod. 2013;39(2):163-72.

58. Anusavice K. Phillips' science of dental materials. $12^{\text {th }}$ edn. Elsevier; 2013.

59. Di Nasso L. Innovations in Shaping and Cleaning the Root Canal System. University Of Florence; 2015.

60. Pawar AM, Pawar MG, Kokate SR. Meant to make a difference, the clinical experience of minimally invasive endodontics with the selfadjusting file system in India. Indian J Dent Res. 2014;25(4):509-12.

61. Pruett J, Clement D, Carnes D. Cyclic fatigue testing of nickel-titanium endodontic instruments. J Endod. 1997;23(2):77-85. 